\title{
Biochemical Estimations of Tetranychus urticae Koch Infested Marigold Leaves in Summer and Winter Seasons under Screen House and Field Conditions
}

\begin{abstract}
Background: African marigolds an important medicinal and ornamental plant is grown throughout the world. The two spotted red spider mite, Tetranychus urticae is one of the most destructive pests of the crop.

Methods: Estimation of various minerals and stress measures of $T$. urticae infested and non infested leaves was performed in two seasons namely summer and winter under both screen house and field conditions. ANOVA was analysed under two factorial Completely Randomized Design. Mite population per leaf was correlated with each biochemical measures and statistical significance of data was analyzed.

Result: Significantly lower nitrogen, phosphorous and potassium content was recorded in infested $(2.01,0.307,1.509 \%$ dry weight) leaves as compared to uninfested leaves $(2.93,0.387,1.874 \%$ dry weight) respectively. Summer season reported higher per cent loss in mineral content as compared to the winter season. The content of total phenol and proline was significantly more in infested leaves $(18.75 \mathrm{mg} / \mathrm{g}, 57.07 \mu / 100 \mathrm{~g})$ as compared to the uninfested leaves $(11.42 \mathrm{mg} / \mathrm{g}$ and $47.50 \mu / 100 \mathrm{~g})$. The per cent increase of phenol and proline ranged from (43.90 and 20.81\%) in summer and (42.90 and $17.45 \%$ ) in winter, respectively.
\end{abstract}

Key words: Infested, Leaves, Minerals, Stress measures, Two spotted spider mite.

\section{INTRODUCTION}

Tetranychus urticae Koch is one of the world's most dangerous agricultural pests, causing yield losses in a wide range of crops including ornamentals field crops or vegetable crops (Fasulo, 2009; Tehri et al., 2014). Tetranychus genus has been classified into 140 species. T. urticae is identified by a good lateral mount of the male aedeagus NAPPO (2014), belongs to the Tetranychoidea superfamily, which includes spider mites (Tetranychidae) and may be separated from other tetranychoids mostly by the female palp from which silk threads are formed. Marigold (Tagetes erecta L.), a popular flower crop in ornamental horticulture, is one of the most commercially exploited flower crops across the whole world. Due to webbing there is leaf deformation and tissue loss, the underside of leaves may attain a greyish colour. Rinehold et al. (2015) found that two-spotted spider mites can consume 18 to 22 plant cells per minute. Webbing may also indicate the dispersal of the mites. Webbing's primary function is to protect eggs, the colony and these webs can be seen with the naked eye. One of the most critical aspects in agricultural pest growth and reproduction is the nutritional quality of the host plant (Motahari, et al., 2014; Parveen et al., 2021). It causes changes in the biochemical composition of the host plant in addition to mechanical and physiological harm. The current study was done to explore the biochemical reaction of plants by assessing change in nitrogen, phosphate, potassium, phenol and proline content in infested and healthy marigold leaves, taking into account all of the damage symptoms that arise. Spider mites can induce severe defence responses in their
1'Department of Zoology and Aquaculture, Chaudhary Charan Singh Haryana Agricultural University, Hisar-125 004, Haryana, India. 2Department of Civil Engineering, Deenbandhu Chhotu Ram University of Science and Technology, Murthal-131 039, Sonipat, Haryana, India.

Corresponding Author: Karuna Bamel, Department of Zoology and Aquaculture, Chaudhary Charan Singh Haryana Agricultural University, Hisar-125 004, Haryana, India.

Email: karunabamel7@gmail.com

How to cite this article: Bamel, K., Gulati, R. and Bamel, K. (2021). Biochemical Estimations of Tetranychus urticae Koch Infested Marigold Leaves in Summer and Winter Seasons under Screen House and Field Conditions. Agricultural Reviews. DOI: 10.18805/ ag. R-2280.

Submitted: 29-05-2021 Accepted: 09-11-2021 Online: 18-12-2021

hosts. Even in vulnerable plants, these effects can occur after only a few days of infection. Phenols and proline have been discovered to be essential chemical components for insect and mite resistance in various host plants.

\section{MATERIALS AND METHODS}

\section{Plant material and collection of leaf samples}

African marigold plants (133-1-2-Lemon red germplasm) (Fig 1a) were sown for summer (January, 2018) and winter (August, 2018) seasons under screen house and field conditions and the crop was monitored till harvesting season in May, 2018 and March, 2019 for summer and winter season 
crops respectively. When the leaves were naturally infested with T. urticae, leaf samples (infested and uninfested) were collected on a suitable day in each season and were brought to acarology laboratory, Dept. of Zoology, CCSHAU, Hisar. Two leaves each from tender, grown up and older leaf stage were collected. Mixed population of egg (Fig 1b), larva, nymph (Fig 1c) and adult (Fig 1d) was calculated from both adaxial and abaxial surface of leaves under stereo zoom binocular microscope. Average number of mites per leaf were correlated with mineral, phenol and proline content.

\section{Estimation of minerals}

Nitrogen, phosphorous and potassium content in marigold leaves was estimated after feeding by Tetranychus urticae in separate sets, to ascertain the effect of mite feeding on these parameters during summer and winter season. These were compared with non infested leaves acting as control for each set.

\subsection{Digestion of sample for nitrogen estimation}

Under replicated conditions we took powdered material (100 $\mathrm{mg}$ ) into a $100 \mathrm{ml}$ conical flask and $10 \mathrm{ml}$ diacid mixture (Sulphuric acid+ Perchloric acid; 4:1) was added to each of the flask (Fiske and Row, 1925). These flasks were covered with watch glasses and allowed to stand overnight (Fiske and Row, 1925). Afterwards, to dissolve the solid particles, heating was done and a clear colourless solution was obtained.

Then one $\mathrm{ml}$ of $\mathrm{HCl}$ concentrate was added to each sample and again heated so as to get a colourless solution. Allowed the solutions to cool down and made the final volume to $25 \mathrm{ml}$ with 1 per cent $\mathrm{HCl}$ in distilled water. Simultaneously, a blank was also run down without the sample. The thorough mixing of solutions was done and then used for analysis of nitrogen.

\subsection{Nitrogen estimation}

Nitrogen content of leaf was estimated by using the method proposed by Lindner (1944). Into a $50 \mathrm{ml}$ volumetric flask, we took $10 \mathrm{ml}$ aliquot (digested material) and added $2.5 \mathrm{~N}$ sodium hydroxide $(2 \mathrm{ml})$, percent sodium silicate solution $(1 \mathrm{ml})$. This neutralized the excess acid and prevented turbidity. About $5 \mathrm{ml}$ aliquot of this solution was taken in a $10 \mathrm{ml}$ graduated test tube and $0.5 \mathrm{ml}$ of Nessler's reagent was added to it. The test tubes were then allowed to stand for $5 \mathrm{~min}$ so that maximum colour develops. On UV-vis spectrophotometer, at $525 \mathrm{~nm}$ OD of the solution was recorded. Compared the reading for each sample with the standard calibration curve of ammonium sulphate to examine the per cent nitrogen content in marigold leaves.

\section{Phosphorus estimation}

Method of Jackson (1973) was used to estimate the phosphorus content of leaves. We took a $25 \mathrm{ml}$ volumetric flask and added one $\mathrm{ml}$ of aliquot into it. Afterwards, it was diluted by adding $9 \mathrm{ml}$ distilled water. Then one $\mathrm{ml}$ of it was taken in a separate test-tube and added $3.2 \mathrm{ml}$ of distilled

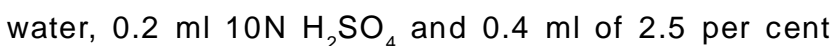
ammonium molybdate into it. Mixed it properly and added $0.2 \mathrm{ml}$ of $1,2,4$ amino naphthol sulphuric acid reagent (freshly prepared) into it. Using UV-vis Spectrophotometer reading was taken at $660 \mathrm{~nm}$.

\section{Potassium estimation}

From the digested sample direct reading (Richards, 1954) were taken using Micro Flame Photometer (Elico CL 361, India) for the estimation of potassium. Fed the instrument with five $\mathrm{ml}$ of sample and for each sample observations were recorded. Standard $\mathrm{KCl}$ for potassium was used to note the potassium content.

\section{Estimation of total phenols}

\subsection{Extraction}

Marigold leaves were powdered for each sample $(500 \mathrm{mg}$ ) and 80 per cent methanol $(30 \mathrm{ml})$ was added to them separately in a $100 \mathrm{ml}$ volumetric flask. Then flasks with samples were placed in water bath $\left(60^{\circ} \mathrm{C}\right)$ for one hour. Afterwards, allowed the flasks to cool down and filtered the contents using Whatman filter paper No.1. Collected the supernatant in $100 \mathrm{ml}$ beakers and using $80 \%$ methanol solution, final volume was made $30 \mathrm{ml}$. The contents were mixed properly. A blank was prepared simultaneously but without the sample.

\subsection{Total phenol}

The extracted content was used for total phenol estimation of uninfested and infested leaves (Swains and Hillis, 1959). $0.5 \mathrm{ml}$ methanolic extract and $7.5 \mathrm{ml}$ distilled water was taken in a test tube and $1 \mathrm{~N}$ of Folin Ciocalteu's Phenol $(1 \mathrm{ml})$ was added to it. It was kept for few minutes and one $\mathrm{ml}$ of saturated $\mathrm{Na}_{2} \mathrm{CO}_{3}$ solution was added to it. The solution was allowed to stand for one hour till the blue colour developed. The absorbance was recorded at $725 \mathrm{~nm}$ using UV spectrophotometer. A blank was prepared using same procedure but without extract in it. A standard curve was prepared with gallic acid and total phenol content was determined.

\section{Estimation of proline}

Estimation of free proline content was done following method of Bates et al. (1973). We took fresh leaf samples $(500 \mathrm{mg}$ ) and homogenized them. Added $5 \mathrm{ml}$ of 3 per cent sulphosalicylic acid to it and centrifuged at 5,000 rpm for 15 min. The supernatant was extracted. The supernatant $(2 \mathrm{ml})$ was mixed with $2 \mathrm{ml}$ of acetic acid and $2 \mathrm{ml}$ of acid ninhydrin. The contents were boiled for 30 minutes and then allowed them to cool down. UV spectrophotometer was used to note the absorbance at $520 \mathrm{~nm}$ and toluene was taken as blank. Graded concentrations of proline in 3 per cent sulphosalicylic acid was used to prepare a standard curve. Proline content was expressed as $\mu \mathrm{g} / 100 \mathrm{mg}$ fresh weight of the leaf tissue. During summer and winter season, per cent loss in photosynthetic pigments, total sugars, non reducing sugars 
and mineral contents were calculated under screen house and field conditions by following formula:

Per cent loss in mineral content $=$

Content in non infested leaf - Content in infested leaf Content in non infested leaf $\times 100$

Per cent increase in total phenols and proline was calculated by following formula during summer and winter season in screen house and field experiments:

Per cent gain in proline/phenol =

Content in infested leaf - Content in non infested leaf Content in infested leaf $\times 100$

\section{Statistical analysis}

'OPSTAT', a standard statistical analysis tool was used for the data analysis. To see the effect of observation place, season and leaf condition on the population dynamics of $T$. urticae, critical difference was calculated by applying ANOVA (Analysis of Variance) through two factorial Completely Randomized Design (CRD) and the statistical significance of data was assessed. Values with same superscript were at par with each other. Correlation coefficient ' $r$ ' was also calculated to see the effect of mite incidence on the biochemical parameters. Correlation variables vary together and are defined by:

$$
r=\frac{\sum(X-\bar{X})(Y-\bar{Y})}{\sqrt{\sum(X-X)^{2}} \sqrt{\sum(Y-Y)^{2}}}
$$

Where,

$X=$ Number of mites.

$X=$ Mean number of mites.

$Y=$ Amount of mineral content/ phenol/proline.

$\mathrm{Y}=$ Mean of mineral content/ phenol/proline.

\section{RESULTS AND DISCUSSION}

Effect of Tetranychus urticae infestation on nitrogen content of African marigold leaves

Nitrogen content was significantly less (2.01\% dry wt.) in infested leaves as compared to uninfested marigold leaves (2.93\% dry weight) $(C D=0.07 ; p=0.05)$ (Table 1$)$. It was 2.33 per cent dry weight in the summer season under screen house conditions which was significantly less than the content recorded at other observation periods $(C D=0.10$; $p=0.05)$. The interaction between observation period and leaf was found to be significant $(C D=0.15 ; p=0.05)$ which indicated that nitrogen content recorded in mite infested leaves differed significantly with each other during seasonal analysis. The significant negative correlation $(r=-0.93)$ between $T$. urticae population and nitrogen content depicted fall in nitrogen content of marigold leaves with increase in T. urticae infestation. The percent loss in nitrogen content ranged between 30.07 to $36.49 \%$ in infested leaves (Fig 2).

\section{Effect of Tetranychus urticae infestation on phosphorous} content of marigold leaves

The results for the estimation of phosphorous contents have been shown in the Table 2. The content of phosphorous differed significantly in infested $(0.307 \%)$ and uninfested leaves $(0.387 \%)(C D=0.006 ; p=0.05)$. Statistically significant difference was observed under field conditions in winter $(0.355 \%)$ and summer season $(0.345 \%)(C D=$ $0.009 ; p=0.05)$.Significant interaction between the observation period and content of phosphorous in marigold leaves was observed $(C D=0.012 ; p=0.05)$ showing lower phosphorous content in infested crop of summer season than winter. Correlation between the mite population and content of phosphorous was found to be -0.99 . It revealed that with increase in mite build up the phosphorous content of leaves decreased. Percent decrease in phosphorous content due to mite infestation in summer $(25.64 \%)$ and winter season (17.63\%) has been shown in Fig 2.

Effect of Tetranychus urticae infestation on potassium content of African marigold leaves

As presented in Table 3, significantly higher potassium content (1.874\% dry weight) was recorded in uninfested plants $(C D=0.017 ; p=0.05)$ as compared to infested leaves ( $1.509 \%$ dry weight). With increase in the number of mites in the range of 25.58 to 61.18 mites per leaf, the leaves started showing bronzing effect (Fig 1e) and were covered with profuse webbing formed by $T$. urticae. Least potassium

Table 1: Effect of Tetranychus urticae infestation on nitrogen content of African marigold leaves.

\begin{tabular}{|c|c|c|c|c|c|}
\hline \multirow{2}{*}{ Observation period } & & \multirow{2}{*}{ No. of mites/leaf } & \multicolumn{2}{|c|}{ Nitrogen content (\%) } & \multirow{2}{*}{ Mean } \\
\hline & & & Infested leaf & Uninfested leaf & \\
\hline \multirow[t]{2}{*}{ Summer } & Screen house & 61.18 & 1.70 & 2.95 & 2.33 \\
\hline & Field & 47.25 & 1.92 & 2.98 & $2.44^{\mathrm{a}}$ \\
\hline \multirow[t]{2}{*}{ Winter } & Screen house & 35.92 & 2.00 & 2.90 & $2.46^{\mathrm{a}}$ \\
\hline & Field & 25.58 & 2.40 & 2.89 & 2.65 \\
\hline Mean & & & 2.01 & 2.93 & \\
\hline Correlation & & & $-0.93^{* *}$ & & \\
\hline
\end{tabular}

CD $(p=0.05)$ for Observation Period $=0.10 ; \mathrm{SE}(\mathrm{m})=0.04$.

CD $(p=0.05)$ for Leaf $(L)=0.07$; SE $(m)=0.02$.

CD $(p=0.05)$ for Observation Period $\times$ Leaf $=0.15$; SE $(m)=0.05$.

Values with the same superscript do not differ significantly.

${ }^{* *}$ Significant at $1 \%$. 


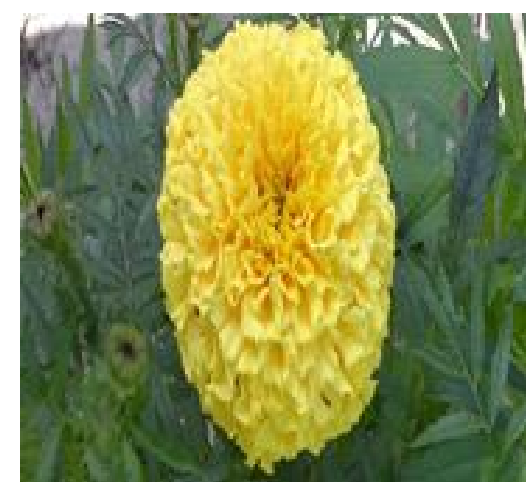

Fig 1(a): Uninfested marigold plant.

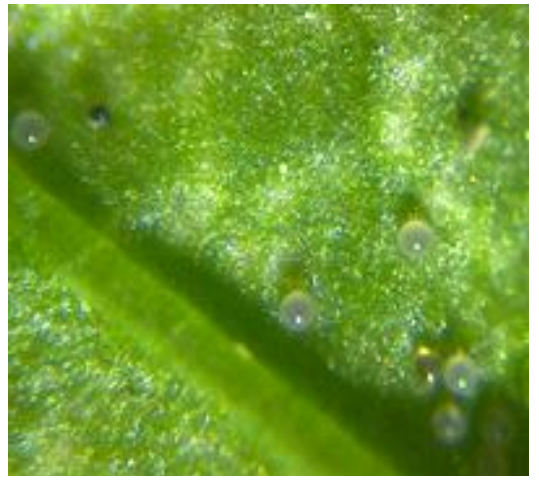

Fig 1(b): Tetranychus urticae eggs.

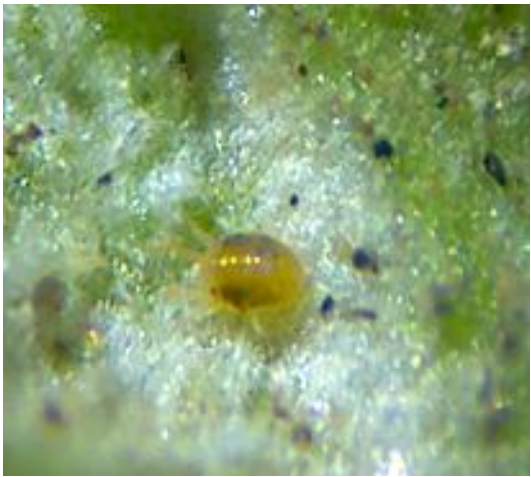

Fig 1(c): Tetranychus urticae nymph with white patches on marigold leaf.

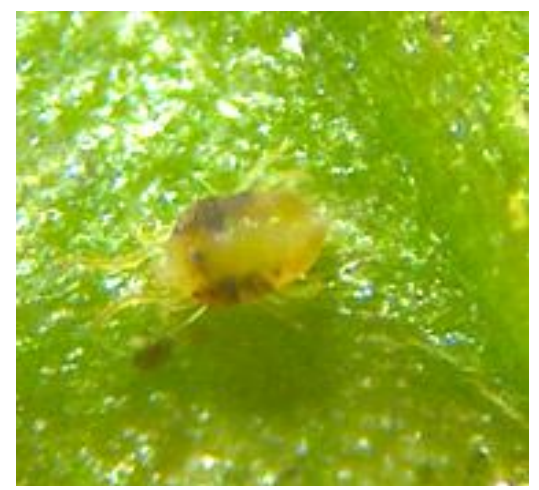

Fig 1(d): Tetranychus urticae adult.

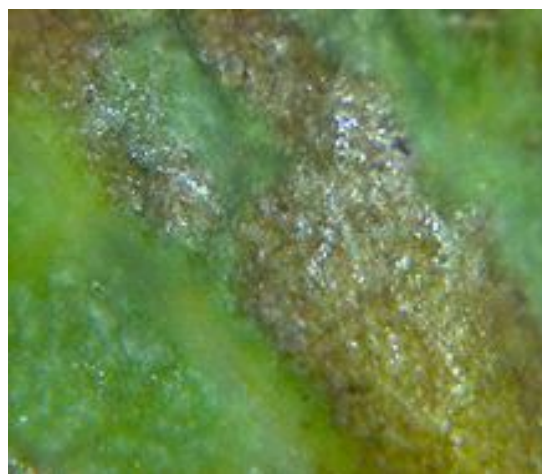

Fig 1(e): Bronzing of leaf surface due to Tetranychus urticae infestation.

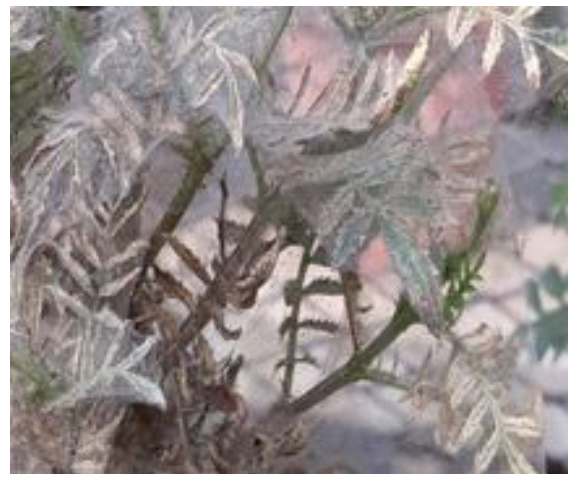

Fig 1(f): Webbing of marigold plant infested with Tetranychus urticae.

content (1.653\% dry wt.) was recorded from marigold leaves under screen house crop during summer season causing 22.54 per cent loss (Fig 2); the value being statistically significant with field crop of the same season $(C D=0.024$; $p=0.05)$. The potassium content was significantly higher in the winter season under screen house (1.707\% dry wt.) and field ( $1.720 \%$ dry wt.) conditions. A significant negative correlation ( $r=-0.99$ ) was recorded between potassium contents of infested marigold leaves and $T$. urticae population which indicated a parallel inverse relationship between the two parameters.

In conformity of present investigation, Hildebrand et al. (1986) reported a decrease in total nitrogen and phosphorus levels in response to $T$. urticae infestation. Farouk and Osman (2011) also reported the same in the bean leaves and observed that it might be due to the fact that infestation with $T$. urticae resulted in increased production of reactive oxygen species (ROS) which destroyed the membrane permeability and thus leading to decreased content of minerals due to its effect on the uptake of ions. Another reason might be less drain of phloem sap by the spider mite population. Kanika (2013) also reported that T. urticae infestation resulted in a percent loss for nitrogen (4.3 to $14.13 \%$ ), phosphorus (5.56 to $16.17 \%$ ) and potassium (5.52 to $7.83 \%$ ) in infested leaves of cucumber. 


\section{Effect of Tetranychus urticae infestation on total phenol content of marigold leaves}

The data generated during the study period showed the mean total phenol content in marigold leaves was 18.75 $\mathrm{mg} / \mathrm{g}$ in infested leaves of marigold which was significantly higher than the total phenol content recorded in uninfested leaves $(C D=0.72 ; p=0.05$ ) (Table 4). It was $16.83 \mathrm{mg} / \mathrm{g}$ and $14.24 \mathrm{mg} / \mathrm{g}$ in screen house marigold plants in both the seasons, respectively showing significant difference with each other and field study $(C D=1.02 ; p=0.05)$. Correlation coefficient $(r=0.99)$ was positive and significant depicting an increase in phenolic content of marigold leaves with increase in number of mites. The percent increase in phenol content ranged between 42.90 to $43.90 \%$ in infested leaves (Fig 3).

Effect of Tetranychus urticae infestation on proline content of marigold leaves

Another stress measure, proline was also found to be increased in marigold leaves subjected to $T$. urticae infestation as compared to uninfested leaves (Table 5).

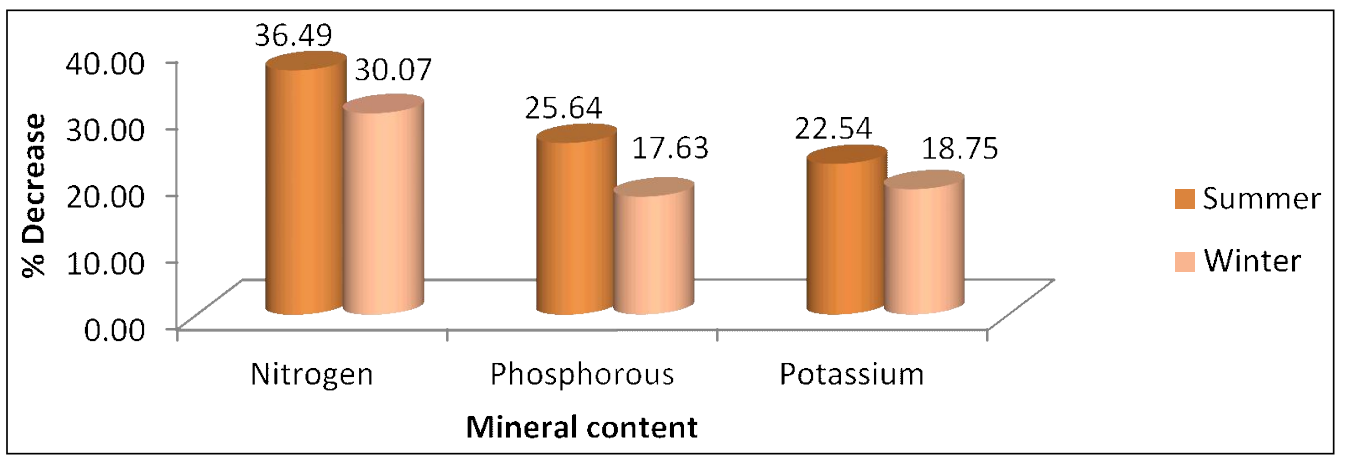

Fig 2: Per cent reduction in mineral contents due to Tetranychus urticae infestation in African marigold leaves.

Table 2: Effect of Tetranychus urticae infestation on phosphorous content of African marigold leaves.

\begin{tabular}{|c|c|c|c|c|c|}
\hline \multirow{2}{*}{ Observation period } & & \multirow{2}{*}{ No. of mites/leaf } & \multicolumn{2}{|c|}{ Phosphorous content (\%) } & \multirow{2}{*}{ Mean } \\
\hline & & & Infested leaf & Uninfested leaf & \\
\hline \multirow[t]{2}{*}{ Summer } & Screen house & 61.18 & 0.290 & 0.390 & $0.340^{\mathrm{a}}$ \\
\hline & Field & 47.25 & 0.300 & 0.390 & $0.345^{a}$ \\
\hline \multirow[t]{2}{*}{ Winter } & Screen house & 35.92 & 0.313 & 0.380 & $0.347^{a, b}$ \\
\hline & Field & 25.58 & 0.323 & 0.387 & $0.355^{b}$ \\
\hline Mean & & & 0.307 & 0.387 & \\
\hline Correlation & & & $-0.99^{* *}$ & & \\
\hline
\end{tabular}

CD $(p=0.05)$ for observation Period $=0.009 ; \mathrm{SE}(\mathrm{m})=0.003$.

CD $(p=0.05)$ for leaf $(L)=0.006$; SE $(m)=0.002$.

$C D(p=0.05)$ for observation Period $\times$ Leaf $=0.012$; SE $(m)=0.004$.

Values with the same superscript do not differ significantly.

${ }^{* *}$ Significant at $1 \%$.

Table 3: Effect of Tetranychus urticae infestation on potassium content of African marigold leaves.

\begin{tabular}{lcccr}
\hline \multirow{2}{*}{ Observation period } & \multirow{2}{*}{ No. of mites/leaf } & \multicolumn{2}{c}{ Potassium content (\%) } \\
\cline { 4 - 5 } & & 61.18 & Infested leaf & Uninfested leaf \\
\hline Summer & Screen house & 47.25 & 1.443 & 1.863 \\
Summer & Field & 35.92 & 1.503 & 1.870 \\
Winter & Screen house & 25.58 & 1.530 & 1.883 \\
Winter & Field & & 1.560 & $1.687^{\mathrm{a}}$ \\
Mean & & & 1.509 & $1.707^{\mathrm{a}, \mathrm{b}}$ \\
Correlation & & $-0.99^{* *}$ & $1.720^{\mathrm{b}}$ \\
\hline
\end{tabular}

$C D(p=0.05)$ for observation period $=0.024 ; S E(m)=0.008$.

CD $(p=0.05)$ for leaf $=0.017$; SE $(m)=0.006$.

CD $(p=0.05)$ for observation period $\times$ Leaf $=0.034$; SE $(m)=0.01$.

Values with the same superscript do not differ significantly.

${ }^{* *}$ Significant at $1 \%$. 
Proline content of uninfested marigold leaves was recorded as $47.50 \mu \mathrm{g} / 100 \mathrm{mg}$ fresh weight. Proline content showed an increase in $T$. urticae infested leaves $(57.07 \mu \mathrm{g} / 100 \mathrm{mg}$ fresh weight) $(C D=0.72 ; p=0.05)$. Statistical analysis of $T$. urticae incidence showed a significant effect of observation period $(C D=1.00 ; p=0.05)$ on proline content of marigold leaves. Proline content was significantly more under screen house conditions in the summer season. Statistically significant interaction between the proline and marigold leaves $(C D=1.4 ; p=0.05)$ was observed which indicated that mite infestation caused change in proline content in uninfested and infested leaves. A positive correlation ( $r=$ 0.99 ) was obtained between mite number and proline content. It indicated that as the mite infestation increased, a significant increase in proline content was also recorded in mite infested leaves. The per cent increase (17.45 to $20.81 \%$ ) in proline due to infestation by $T$. urticae under screen house conditions is depicted in Fig 3.

The higher mite intensity in the summer season leads to a higher stress and hence higher content of stress

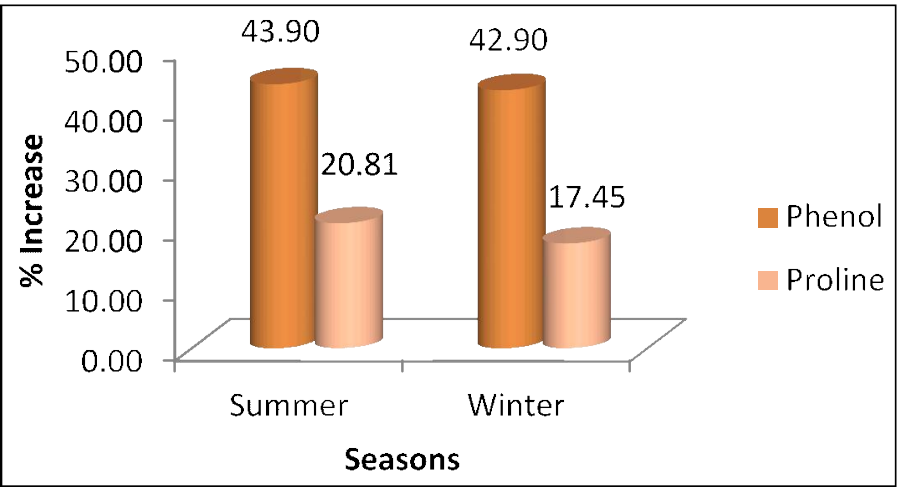

Fig 3: Per cent increase in stress measures (phenol and proline) content due to Tetranychus urticae infestation in African marigold leaves

Table 4: Effect of Tetranychus urticae infestation on total phenol content of African marigold leaves.

\begin{tabular}{|c|c|c|c|c|c|}
\hline \multirow{2}{*}{ Observation period } & & \multirow{2}{*}{ No. of mites/leaf } & \multicolumn{2}{|c|}{ Phenol (mg/g) } & \multirow{2}{*}{ Mean } \\
\hline & & & Infested leaf & Uninfested leaf & \\
\hline Summer & Screen house & 61.18 & 21.42 & 12.23 & 16.83 \\
\hline Summer & Field & 47.25 & 19.02 & 12.28 & 15.65 \\
\hline Winter & Screen house & 35.92 & 18.15 & 10.33 & $14.24^{\circ}$ \\
\hline Winter & Field & 25.58 & 16.40 & 10.83 & $13.62^{\circ}$ \\
\hline Mean & & & 18.75 & 11.42 & \\
\hline Correlation & & & $0.99^{* *}$ & & \\
\hline
\end{tabular}

$\mathrm{CD}(\mathrm{p}=0.05)$ for observation Period $=1.02 ; \mathrm{SE}(\mathrm{m})=0.33$

$\mathrm{CD}(\mathrm{p}=0.05)$ for leaf $=0.72$; SE $(\mathrm{m})=0.24$

CD $(p=0.05)$ for observation Period $\times$ Leaf $=1.4 ;$ SE $(m)=0.48$

Values with the same superscript do not differ significantly

${ }^{* *}$ Significant at $1 \%$

Table 5: Effect of Tetranychus urticae infestation on proline content in African marigold leaves.

\begin{tabular}{|c|c|c|c|c|c|}
\hline \multirow{2}{*}{ Observation period } & & \multirow{2}{*}{ No. of mites/leaf } & \multicolumn{2}{|c|}{ Proline $(\mu \mathrm{g} / 100 \mathrm{~g})$} & \multirow[b]{2}{*}{ Mean } \\
\hline & & & Infested leaf & Uninfested leaf & \\
\hline Summer & Screen house & 61.18 & 61.03 & 48.33 & 54.68 \\
\hline Summer & Field & 47.25 & 57.75 & 48.83 & 53.29 \\
\hline Winter & Screen house & 35.92 & 56.33 & 46.50 & 51.42 \\
\hline Winter & Field & 25.58 & 53.15 & 46.33 & 49.74 \\
\hline Mean & & & 57.07 & 47.50 & \\
\hline Correlation & & & $0.99^{* *}$ & & \\
\hline
\end{tabular}

$C D(p=0.05)$ for observation period $=1.00 ; \mathrm{SE}(\mathrm{m})=0.58$.

$C D(p=0.05)$ for leaf $=0.72$; SE $(m)=0.41$.

CD $(p=0.05)$ for observation period $\times$ Leaf $=1.4$; SE $(m)=0.82$.

${ }^{* *}$ Significant at $1 \%$. 
measures in the plant. Increased level of total phenols following infestation with the pests had been reported by many workers (Madhavi et al., 2005; Theerthagiri et al., 2007). The results of present investigation are also supported by the findings of Senthil et al. (2010), who reported increased total phenols in plants infected by fungus and stated that increase in phenol content was a kind of plant defence system as they might play an important role in increasing the mechanical and physical strength of the host cell wall. Larson and Berry (1984) reported that total phenolics were strongly negatively related to $T$. urticae development and oviposition. Similarly, increase of proline content after T. urticae infestation is an indicator, signalling biotic stress intensity. Due to mite's attack, the plant is under the oxidate stress and raised levels of proline mite function in ROS detoxification and stabilization of cell membranes (Kishor et al., 2005). Kanika (2013) found increased. proline percentage from 9.79 to 25.72 as compared to control in $T$. urticae inoculated leaves while total phenols increased from 11.42 to 31.42 per cent after initial inoculation of $5,10,15$ and 20 mites/grown up leaf at 20, 40 and 60 days of infestation over the control.

\section{CONCLUSION}

Mite infestation decreases the content of minerals like nitrogen, phosphorous and potassium in leaves. Due to seasonal incidence of $T$. urticae, summer season accounts more T. urticae per leaf. This leads to more loss of minerals in summer season as compared to that in winter season crop. Similary, due to mite infestation the plants are under stress and this is proved with greater content of stress measures such as phenol and proline in infested leaves as compared to uninfested marigold leaves.

\section{REFERENCES}

Bates, L.S., Waldran, R.P. and Teare, I.D. (1973). Rapid determination of free proline for water stress studies. Plant Soil. 39: 205-208.

Farouk, S. and Osman, M.A. (2011). The effect of plant defense elicitors on common bean (Phaseolus vulgaris L.) growth and yield in absence or presence of spider mite (Tetranychus urticae Koch) infestation. Journal of Stress Physiology and Biochemistry. 7(3): 6-22.

Fasulo, T.R. (2009). Common name: Two Spotted Spider Mite, Scientific Name: Tetranychusurticae Koch (Arachnida: Acari: Tetranychidae). In: Featured creatures, Entomology and Nematology. [J.L. Gillett-Kaufma (Ed.)]. University of Florida, DPI Entomology Circular. http://edis.ifas.ufl. edu/in307.

Fiske, C.H. and Row, Y. (1925). The colorimetric determination of phosphorus. Journal of Biological Chemistry. 66: 375-400.

Hildebrand, D.F., Rodriguez, J.G., Brown, G.C. and Volden, C.S. (1986). Two spotted spider mite (Acari: Tetranychidae) infestations on soybeans: Effect on composition and growth of susceptible and resistant cultivars. Journal of Economic Entomology. 79(4): 915-921.
Jackson, M.L. (1973). Vanamolybdate Phosphoric Yellow Colour Method for Determination of Phosphorus. Soil Chemical Analysis, Prentice Hall of India Pvt. Ltd. New Delhi.

Kanika, (2013). Damage potential of Tetranychus urticae Koch and its management in Cucumis sativus Linnaeus. Ph.D. thesis, CCS HAU, Hisar.

Kishor, P.B., Sangam, S., Amrutha, R.N., Sri Laxmi, P., Naidu, K.R., Rao, K.R.S.S., Rao, S., Reddy, K.J., Theriappan, P. and Sreenivasulu, N. (2005). Regulation of proline biosynthesis, degradation, uptake and transport in higher plants: Its implications in plant growth and abiotic stress tolerance. Current Sciences. 88(3): 424-438.

Larson, K.C. and Berry, R.E. (1984). Influence of peppermint phenolics and monoterpenes on two spotted mite (Acari: Tetranychidae). Environmental Entomology. 13: 282-285.

Lindner, R.C. (1944). Rapid analytical methods for some inorganic constituents in plant tissue. Plant Physiology. 19: 76-86.

Madhavi, K.J., Sujatha, M., Reddy, D. and Chander, R. (2005). Biochemical characterization of resistance against Alternaria helianthiin cultivated and wild sunflower. Helia. 28(43): 13-24.

Motaheri, M., Katayoon, K., Rostaee, A.M. and Talebi, A.A. (2014). The impact of cucumber nitrogen nutrition on life history trait of Tetranychus urticae Koch (Acari: Tetranychidae). Acarologia. 54(4): 443-452.

NAPPO (2014). Morphological identification of spider mites (Tetranychidae) affecting important fruits. North American Plant Protection Organization. pp. 30.

Parveen, S.S., Ramaraju, K. and Jeyarani, S. (2021). Entomopathogenic fungal screening against two spotted spider mites, Tetranychus urticae Koch in tomato and broad mite, Polyphagotarsonemus latus (Banks) in Chilli. Indian Journal of Agricultural Research. 55(4): 488-492. DOI: 10.18805/IJARe.A-5661.

Richards, L.A. (1954). Diagnosis and improvement of saline and alkaline soils. USDA Handbook No. 60.

Rinehold, J., Bell, N. and Waters, T. (2015). Vegetable crops, vegetable pests. In Insect hand book. (pp. 1-20).

Senthil, V., Ramasamy, P., Elaiyaraja, C. and Elizabeth, A.R. (2010). Some phytochemical properties affected by the infection of leaf spot disease of Cucumis sativus (Linnaeus) caused by Penicillium notatum. African Journal of Basic and Appllied Sciences. 2(3): 64-70.

Swains, T.H. and Hillis, W.E. (1959). Phenolic constituent of Prunus domestica $\mathrm{L}$. the quantitative analysis of phenolic constituent. Journal of Science and Food Agriculture. 10: 63-69.

Tehri, K., Gulati, R. and Geroh, M. (2014). Host Plant Responses, Biotic Stress and Management Strategies for the control of Tetranychus urticae Koch (Acarina: Tetranychidae) Agri. Review. 35(4): 250-260.

Theerthagiri, A., Raguchander, T., Karthkeyan, G., Prakasam, V. and Samiyappan, R. (2007). Chemically and biologically mediated systemic resistance in cucumber (Cucumis sativus L.) against Pseudoperonospora cubensis and Erysiphe cichoracearum. Phytopathogia Mediterranea. 46: 259-271. 